Doi: HTTPS://DOI.ORG/10.23910/2/2021.0431a

\title{
GIS based Land Use Suitability of Diversified Cropping Systems in Bareli Watershed
}

\author{
Sagar N. Ingle ${ }^{1 *}$, M. S. S. Nagaraju², Priya S. Gadge ${ }^{1}$, D. P. Deshmukh ${ }^{1}$ and N. R. Dange ${ }^{1}$ \\ ${ }^{1}$ Dr. Panjabrao Deshmukh Krishi Vidyapeeth, Akola (444 104), India \\ ${ }^{2}$ ICAR-National Bureau of Soil Survey and Land Use Planning, Nagpur (440 033), India
}

\section{Corresponding Author}

Sagar N. Ingle

e-mail: sagaringle345@gmail.com

\author{
Article History \\ Article ID: IJEP0431a \\ Received on $06^{\text {th }}$ July, 2021 \\ Received in revised form on $03^{\text {rd }}$ November, 2021 \\ Accepted in final form on $22^{\text {nd }}$ November, 2021
}

\begin{abstract}
A study was undertaken to evaluate the soils in Bareli watershed, Seoni district of Madhya Pradesh for sustainable land use planning. Five soil series namely, Diwartola, Diwara, Bareli-1, Bareli-2 and Bareli-3 were tentatively identified and mapped into twenty-four mapping units and a soil map was generated using remote sensing and Geographic Information System (GIS) techniques. The land information generated during soil survey has been used to evaluate land capability, land irrigability, soil productivity and soil-site suitability for some medicinal, aromatic and spices crops. The soils were grouped into land capability sub-classes IVs and IVst and land irrigability sub-classes 2 st, $3 \mathrm{~s}, 3$ st and 4st. Soils of Diwartola, Bareli-1 and Bareli-3 were average and soils of Diwara and Bareli-2 were poor in soil productivity based on limitations of erosion, drainage and physicochemical properties. Soil-site suitability assessment reveals that soils of Bareli-1 were moderately suitable (S2) for cultivation of medicinal and spices crops like Ashwagandha, Mucana, Davana, Lemongrass, Turmeric and Ginger with moderate limitations of effective depth and slope, while, soils of Diwartola and Bareli-3 were marginally suitable (S3) for cultivation of these crops.
\end{abstract}

Keywords: GIS, remote sensing, soil suitability

\section{Introduction}

Indian sub-continent is blessed with most diverse soil and climatic conditions, which are suitable for the growth of many medicinal and aromatic plant species. In India, medicinal and aromatic plants are grown in large scale and their products are being exported to various countries for their huge demand (Rajendran et al., 2008 and Dharumrajan et al., 2016).

Land needs careful and appropriate use that is vital to achieve optimum productivity and to ensure environmental sustainability for future generation. This requires an effective and operative management of land information on which such decisions should be based because land is one of the non-renewable natural resources. Decision on appropriate use includes the past and present human activities) and the status of physical and chemical properties of the land (Keshavarzi et al., 2011). Land evaluation (LE) is concerned with the assessment and valuation of land when used for specified purposes. It involves the execution and interpretation of basic surveys of data on climate, soils, vegetation and other aspects of land in terms of the requirements of alternative forms of land use. To be of value in planning, the range of land uses considered has to be limited to those which are relevant within the physical, economic and social context of the area considered (FAO, 1976). Land evaluation is a foundation for sustainable land resource planning and management since it helps us to know whether the resources are degraded or enhanced in quality (Dumanski et al., 2002; Mohana et al., 2009). Continuous utilization of agriculture land in past decades, regardless of land suitability has caused much more destruction than provide the resources. Land evaluation for diversified cropping system, particularly for medicinal, aromatic and spices plants will help the farmers to improve the productivity of their lands for better value to their produce.

Keeping these in view, land evaluation exercise was undertaken by utilizing the spatial soil information generated during the soil survey of Bareli watershed in Seoni district of Madhya Pradesh for land resources management for sustained land use.

\section{Materials and Methods}

\subsection{Study area}

The Bareli watershed in basaltic terrain, lies between $22^{\circ} 29^{\prime}$ $39^{\prime \prime}$ to $22^{\circ} 32^{\prime} 10^{\prime \prime} \mathrm{N}$ latitudes and $79^{\circ} 46^{\prime} 44^{\prime \prime}$ to $79^{\circ} 49^{\prime} 50^{\prime \prime} \mathrm{E}$ longitudes and covers an area of 1795.35 ha in Dhanora block, Seoni district, Madhya Pradesh (Figure 1). Physiographically, Bareli watershed was divided into five major physiographic units viz. plateau $(P)$, escarpments $(E)$, hills and ridges $(H)$, isolated mounds (M) and pediments (D). The elevation of 


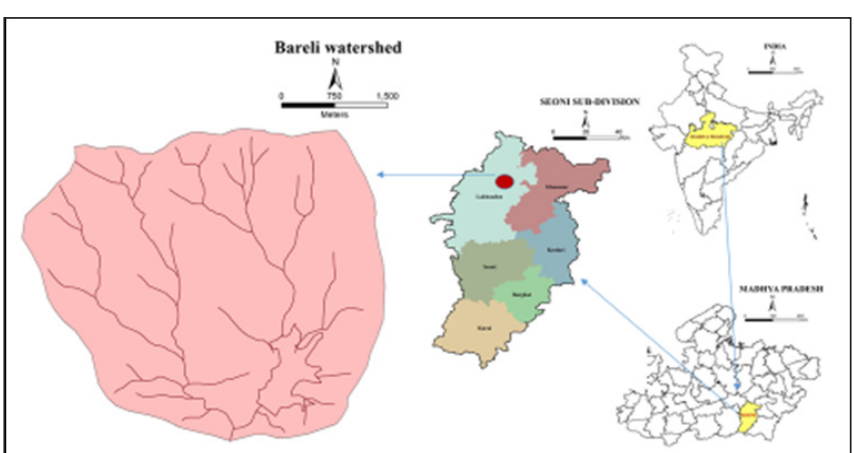

Figure 1: Location of study area

the area ranges from 520 to $620 \mathrm{~m}$ above mean sea level (MSL). The area is associated with level to nearly level sloping $(0-1 \%)$ to moderately steep to steeply sloping (15$25 \%)$ lands. The climate is mainly dry sub-tropical with mean annual temperature of $28.4^{\circ} \mathrm{C}$ and mean annual rainfall of $1100 \mathrm{~mm}$. The area qualifies for ustic soil moisture regime and hyperthermic soil temperature regime, respectively. The natural vegetation comprises of teak (Tectona grandis), babul (Acacia spp), palas (Butea frandosa), charoli (Buchanania lanzan), ber (Ziziphus jujuba) etc.

A detailed soil survey was carried out using IRS P-6 LISS-IV (5.8 $m$ spatial resolution) in the scale of $1: 10000$. Survey of India (SOI) toposheet No. 55 N/14 and 55 N/15 (1:50000 scale) was used to collect topographic and location information. The pedons were exposed and studied for their morphological properties following the procedure outlined by Soil Survey Staff (2003). The physicochemical properties (horizon-wise) were estimated following standard procedures. Important soil-site and physico-chemical properties of soils of Bareli watershed are presented in Table 1.

Five soil series were identified in the study area and a soil map has been developed (Figure 2a) and used for land evaluation. Land capability (Klingebiel and Montgomery, 1961), land irrigability (AIS \& LUS, 1971) and soil productivity (Requier et al., 1970) has been worked out. The soil-site suitability analysis (Naidu et al., 2009) was done for evaluating the suitability of different mapping units for Ashwgandha, Mucana, Davana, Lemongrass, Tulsi, Turmeric and Ginger. ArcGIS software was used for generation of various spatial thematic maps.

Table 1: Soil-site and physico-chemical properties of soils of Bareli watershed

\begin{tabular}{|c|c|c|c|c|c|c|c|c|c|c|}
\hline \multirow[t]{2}{*}{ Soil Series } & \multicolumn{4}{|c|}{ Soil-site characteristics } & \multicolumn{6}{|c|}{ Physico-chemical characteristics } \\
\hline & $\begin{array}{l}\text { Slope } \\
(\%)\end{array}$ & Erosion & Drainage & Drainage & Texture & $\begin{array}{c}\mathrm{pH} \\
(1: 2.5)\end{array}$ & $\begin{array}{c}\mathrm{EC} \\
\left(\mathrm{dS} \mathrm{m}^{-1}\right)\end{array}$ & $\begin{array}{l}\mathrm{OC} \\
(\%)\end{array}$ & $\begin{array}{l}\text { CEC (cmol } \\
(p+)\left(\mathrm{kg}^{-1}\right)\end{array}$ & $\begin{array}{c}\mathrm{CaCO}_{3} \\
(\%)\end{array}$ \\
\hline Diwartola & $3-8$ & Moderate & Well Drained & 36 & $\mathrm{C}$ & 6.73 & 0.13 & 0.85 & 51.1 & 4.3 \\
\hline Diwara & $1-3$ & Moderate & Well Drained & 35 & C & 7.11 & 0.18 & 0.58 & 43.5 & 5.8 \\
\hline Bareli-1 & $1-3$ & Very severe & Well Drained & 60 & $\mathrm{C}$ & 7.22 & 0.36 & 0.56 & 51.2 & 7.9 \\
\hline Bareli-2 & $3-8$ & Severe & Well Drained & 15 & $\mathrm{C}$ & 6.36 & 0.13 & 0.67 & 51.1 & 3.2 \\
\hline Bareli-3 & $8-15$ & Severe & Well Drained & 32 & $\mathrm{C}$ & 7.05 & 0.17 & 0.58 & 48.5 & 2.6 \\
\hline
\end{tabular}
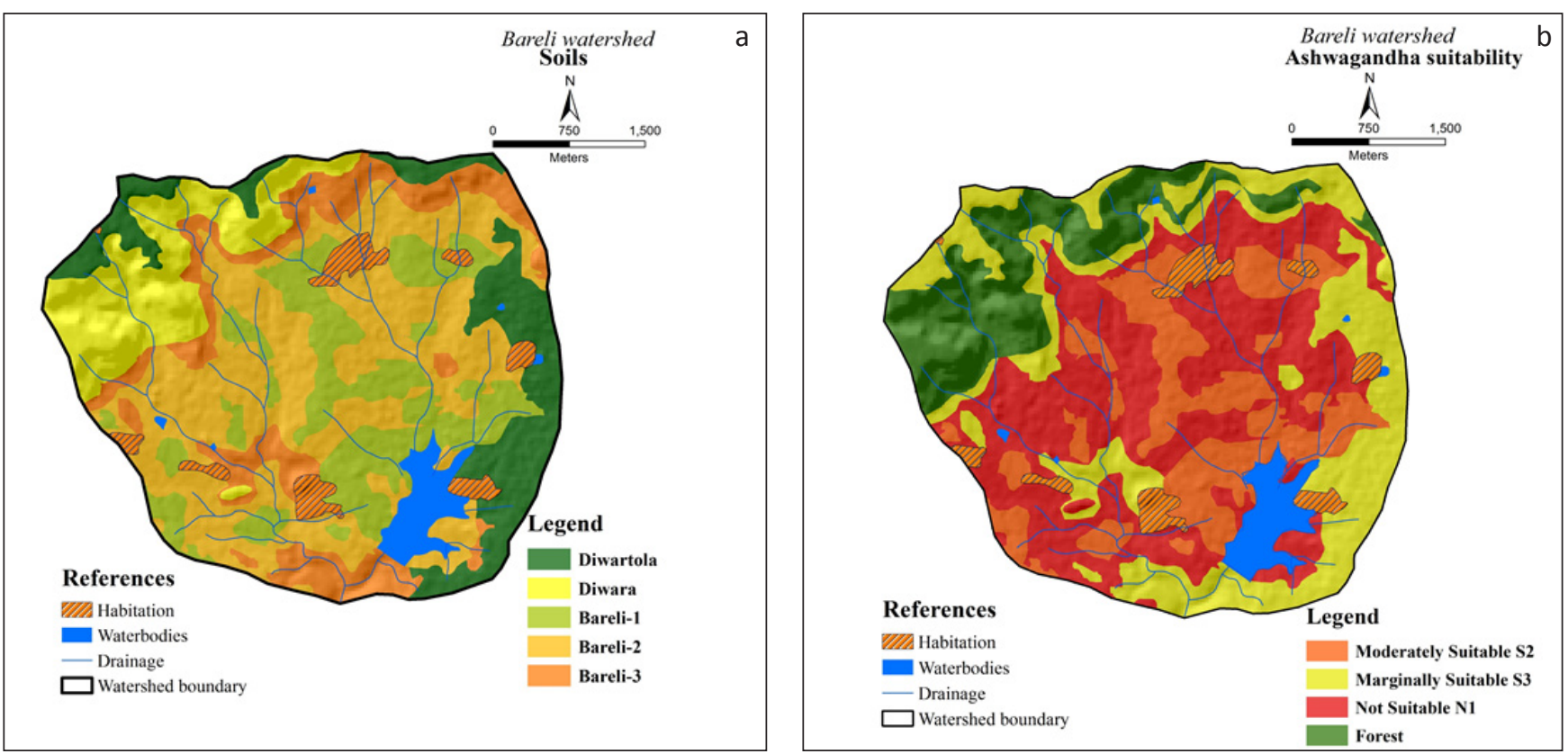

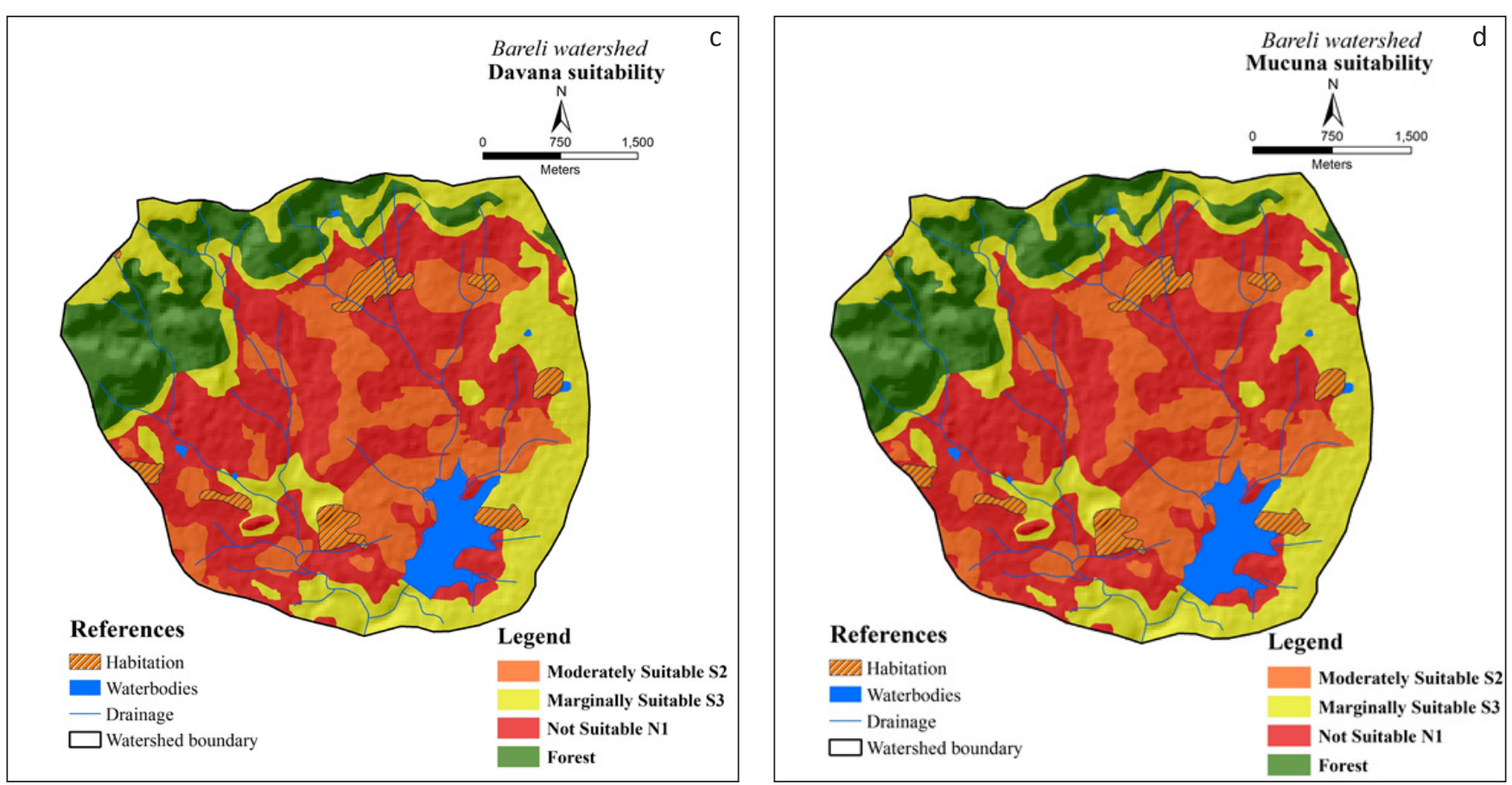

Figure 2: a) soil map and soil-site suitability for b) Ashwagandha c) Davana and d) Mucuna

\section{Results and Discussion}

\subsection{Land capability, land irrigability and soil productivity}

Site characteristics of soil units are given in Table 2 and are matched with the criteria for land capability classification (LCC). The results (Table 2 ) indicated that soils of Diwartola, Diwara and Bareli-1 are fairly good cultivable lands with severe limitations due to soil depth, surface stoniness, texture and coarse fragments and soils of Bareli-2 and Bareli-2 are fairly good cultivated lands with severe limitations due to soil depth, slope, erosion, and coarse fragments. The land capability sub-classes in different mapping units were mapped as IVs and IVst and cover $45.0,48.1 \%$ of TGA, respectively. Land irrigability evaluation (Table 2 ) indicated that soils of Bareli-1 were grouped under land irrigability sub-class 2 st with minor limitations of soil texture and slope and moderate limitations of texture and drainage. The soils of Diwartola are grouped under $3 \mathrm{~s}$ with severe limitations of soil depth, surface texture, soil permeability, coarse fragments and available water holding capacity. The soils of Bareli-3 are grouped under 3st

Table 2: Land capability, land irrigability and soil productivity in Bareli watershed

\begin{tabular}{llccc}
\hline $\begin{array}{l}\text { Sl. } \\
\text { No. }\end{array}$ & Soils & $\begin{array}{c}\text { Land } \\
\text { capability }\end{array}$ & $\begin{array}{c}\text { Land } \\
\text { irrigability }\end{array}$ & $\begin{array}{c}\text { Soil } \\
\text { productivity }\end{array}$ \\
\hline 1. & Diwartola & IVs & $3 s$ & Average \\
2. & Diwara & IVs & 4 st & Poor \\
3. & Bareli-1 & IVs & 2 st & Average \\
4. & Bareli-2 & IVst & 4 st & Poor \\
5. & Bareli-3 & IVst & 3 st & Average \\
\hline
\end{tabular}

with severe limitations of soil depth, slope, surface texture, soil permeability, coarse fragments and available water holding capacity. The soils of Diwara, Bareli-2 are grouped under 4st with very severe limitations of soil depth, surface texture, slope, soil permeability, coarse fragments and available water holding capacity. Soil productivity evaluation (Table 2) indicated that soils of Diwara and Bareli-2 are poor in productivity due to very severe limitations soil depth, soil moisture and soil organic matter. Soils of Diwartola, Bareli-1 and Bareli-3 are average in productivity due to severe limitations of soil depth and soil moisture.

\subsection{Soil-site suitability evaluation for medicinal and aromatic plants}

The optimum requirements of a crop are always region specific. Climate and soil-site parameters play significant role in maximizing the crop yields. The kind and degree of limitations were evaluated and soil properties were matched with soil site suitability criteria for various Medicinal and aromatic crops of the area (Naidu et al., 2009).

Ashwagandha (Withania somnifera) is a short, tender annual to perennial, branched, undershrub to herb growing $35-75 \mathrm{~cm}$ tall and requires less amount of rainfall with moderately shallow to moderately deep-rooted system. Hence, soils which are deep and have high clay content are suitable for Aswagandha. The evaluation for suitability (Table 3 ) indicated that soils of Bareli-1 were moderately suitable with severe limitation of effective soil depth, whereas, soils of Diwartola and Bareli-3 are marginally suitable (S3) with marginal limitations of soil depth and slope, while, soils of Diwara and Bareli-2 are not suitable (N1) for growing Aswagandha due to very severe limitations of soil depth, slope and coarse 


\begin{tabular}{lllllcccc}
\hline \multicolumn{7}{l}{ Table 3: Soil-site suitability for different crops in Bareli watershed } \\
\hline S1. No. & Soils & Ashwa gandha & Davana & Mucuna & Lemon grass & Tulsi & Ginger & Turmeric \\
\hline 1. & Diwartola & S3 & S3 & S3 & S3 & S3 & S3 & S3 \\
2. & Diwara & N1 & N1 & N1 & N1 & N1 & N1 & N1 \\
3. & Bareli-1 & S2 & S2 & S2 & S2 & S2 & S2 & S2 \\
4. & Bareli-2 & N1 & N1 & N1 & N1 & N1 & N1 & N1 \\
5. & Bareli-3 & S3 & S3 & S3 & S3 & S3 & S3 & S3 \\
\hline
\end{tabular}

fragments. Similar results of non-suitability of Ashwagandha due to shallow depth were reported by Ramamurthy and Singh (2015) and Dharumrajan et al. (2016).

The Mucuna (Mucuna pruriens) widely known as 'velvet bean' is a vigorous annual climbing legume originally from southern China and eastern India and its seeds are potentially of substantial medicinal importance. The crop can be grown on wide range of soils; however, it grows well on well drained sandy to clay loam type soils having proper drainage. The plant can withstand the drought conditions. The suitability evaluation (Table 3 ) indicated that soils of Bareli-1 were moderately suitable with moderate limitations of effective rooting soil depth, whereas, soils of Diwartola and Bareli-3 are marginally suitable (S3) with marginal limitations of effective soil depth and coarse fragment and erosion hazard; slope, while, soils of Diwara and Bareli-2 are not suitable (N1) for growing Mucuna due to very severe limitations of soil depth, slope and coarse fragments.

Davana (Artemisia pallens Wall) is a short duration crop and it is commercially cultivated for its fragrant leaves and flowers. The suitability evaluation (Table 3 ) indicated that soils of Bareli-1 were moderately suitable with moderate limitations of effective rooting soil depth, and soils of Diwartola and Bareli-3 are marginally suitable (S3) with marginal limitations of effective soil depth and coarse fragment and erosion hazard; slope, while, soils of Diwara and Bareli-2 are not suitable (N1). The results were in close conformity with the results of (Natarajan et al., 2010). The spatial suitability maps of Ashwagandha, Mucuna and Davana are presented in Figure $2 \mathrm{~b}$, Figure $2 \mathrm{c}$ and Figure $2 \mathrm{~d}$.

Lemongrass (Cymbopogon spp) is widely used as a culinary herb in Asian cuisines and also as a medicinal herb in India. It has a subtle citrus flavor and can be dried and powdered, or used fresh. It is innumerable use in perfumery, flavouring and medicine. It is a very hardy crop adapted to a variety of soil and climatic conditions. The plant requires a warm tropical climate, intermittent but not very excessive rainfall and plenty of sunshine. The suitability evaluation (Table 3 ) indicated that soils of Bareli-1 were moderately suitable with moderate limitations of effective rooting soil depth, and soils of Diwartola and Bareli-3 are marginally suitable (S3) with marginal limitations of effective soil depth and coarse fragment and erosion hazard; slope, while, soils of Diwara and Bareli-2 are not suitable (N1). Suitability of soils with similar constraints for the cultivation of moderately shallow rooted medicinal and oilseed crops were reported by Sharma et al. (1972). However, some species show the adaptability to slightly acidic to alkaline soils.

Tulsi (Ocimum sanctum Linn), the most sacred herbs in Ayurveda and considered good for the lungs and strengthens the adrenals (Cohen, 2014). Tulsi grows well in rich clay loamy soil with sufficient precipitation (Ramamurthy and Singh, 2015). The results indicated that (Table 3 ) soils of Bareli-1 were moderately suitable with severe limitation of effective soil depth, whereas, soils of Diwartola, and Bareli-3 are marginally suitable (S3) with marginal limitations of soil depth, slope and the soils of Diwara and Bareli-2 are not suitable (N1) for growing Tulsi due to very severe limitations of soil depth, slope and coarse fragments. The results were in close conformity with the results of Natarajan et al. (2010) and Dharumrajan et al. (2016). The spatial suitability maps of Lemongrass and Tulsi are presented in Figure $3 \mathrm{a}$ and Figure $3 \mathrm{~b}$.

\subsection{Soil-site suitability evaluation for spices}

Soil-site suitability for major spices crops like turmeric and ginger that are grown in Madhya Pradesh region was

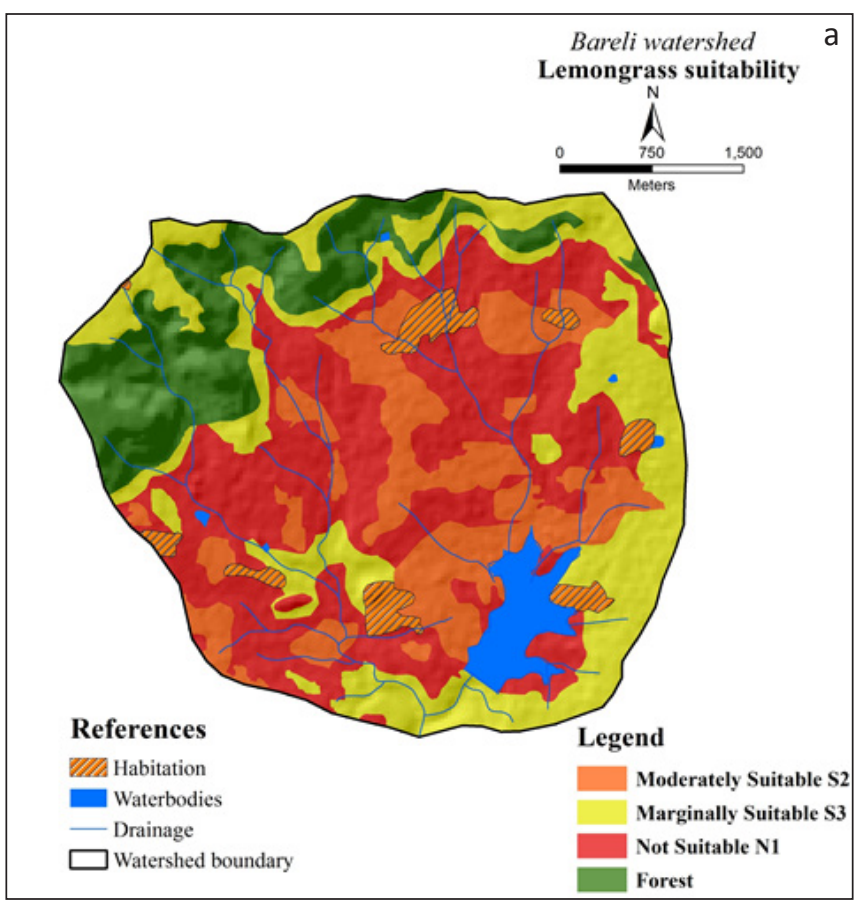

Figure 3: Continue... 

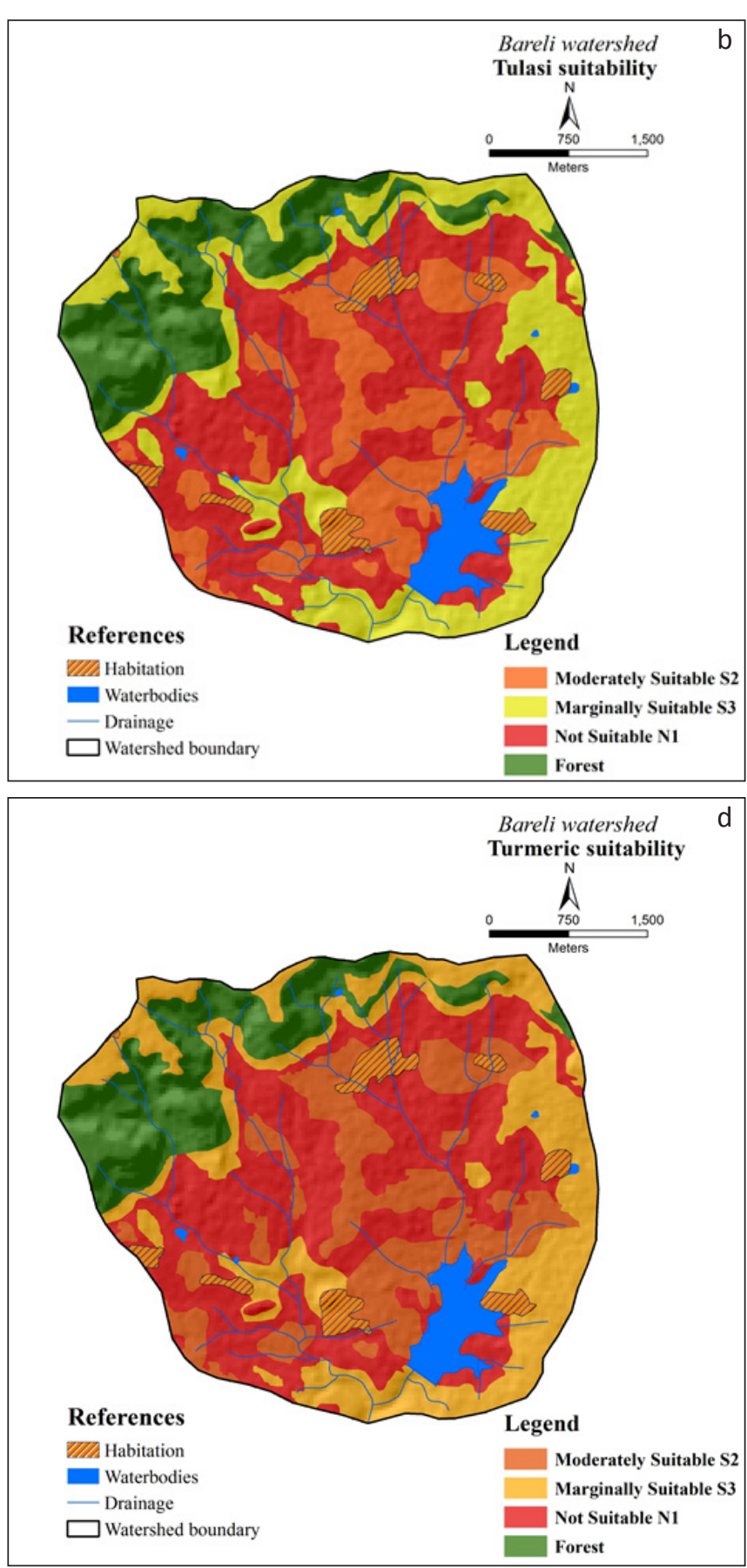

Figure 3: a) Soil-site suitability for a) Lemongrass b) Tulsi c) Ginger and d) Turmeric

evaluated (Table 3). Soil depth, slope and soil pH are major factors to be considered for recommendation and cultivation of spices crops. Among the different soil series of the watershed, Diwara and Bareli-2 series are not suitable due to shallow rooting depth $(<25 \mathrm{~cm})$ and slope. Similar results of non-suitability due to effective depth and slope were reported by Bobade et al. (2010). Soils of Diwartola Bareli-1 and Bareli-3 series are moderately to marginally suitable for cultivation of these spices' crops, nevertheless, with certain

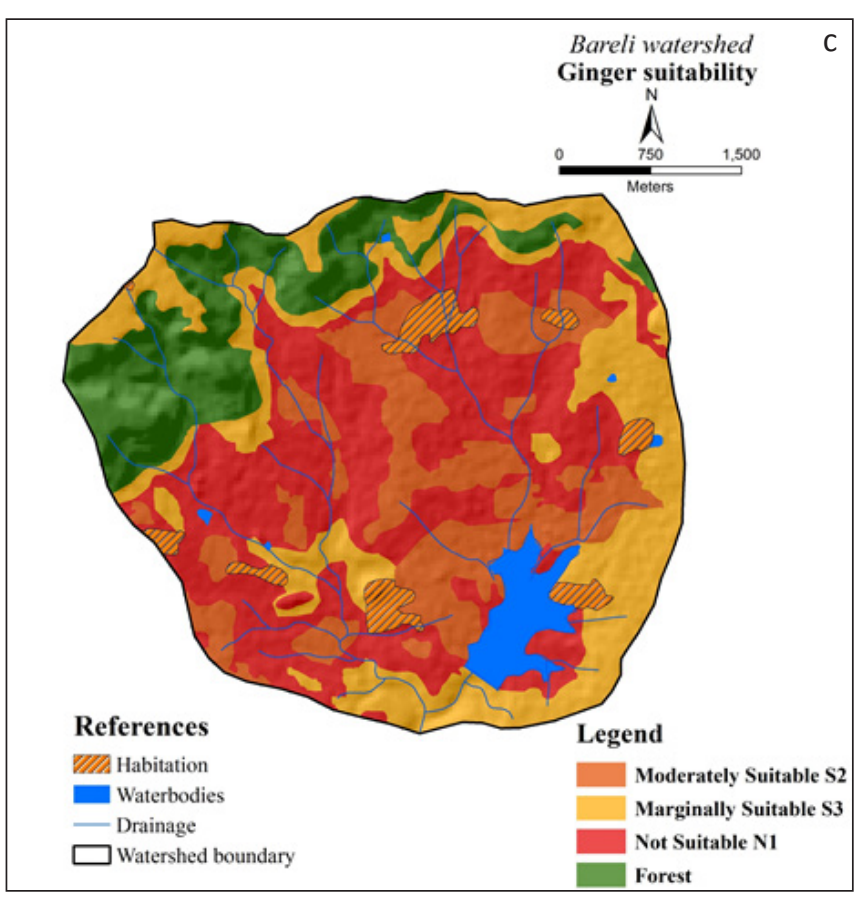

limitations like effective rooting depth and slope. The results were close conformity with the results of Amara et al. (2013) and Amara et al. (2016). The spatial suitability maps of Ginger and Turmeric are presented in Figure $3 c$ and Figure $3 d$.

\section{Conclusion}

Land evaluation plays a vital role in land use planning and helps the decision makers in initiating a suitable management of agricultural resources. In the present work, the soil information generated from soil survey of Bareli watershed of Seoni district of Madhya Pradesh has been used for evaluating the land capability, land irrigability, soil productivity and suitability of soils for medicinal, aromatic and spices crops which has better economic value to the farmers. The area has fairly good cultivated lands with moderate to marginal limitations for sustained use under irrigation.

\section{References}

AIS \& LUS, 1971. Soil Survey Manual, All India Soil and Land Use survey (AIS \& LUS) publication, IARI, New Delhi: $121 p$.

Amara, D.M.K., Patil, P.L., Dasog, G.S., Manjunath, M.V., 2013. Rainfall erosivity (R-Factor) estimation for Singhanhallibogur microwatershed in Northern Transition Zone of Karnataka. Research Journal of Agricultural Sciences 4 (5/6), 644-664

Amara, D.M.K., Sawyerr, P.A., Mansaray, S.D., Kamanda, P.J., 2016. Assessment of soil productivity potentials in hot semi-arid Northern transition zone of India using riquier Index and GIS techniques. Asian Journal of Agriculture and Food Sciences 4(1), 1-17.

Bobade, S.V., Bhaskar, B.P., Gaikawad, M., Raja, S.P., Gaikwad, S.S., Anantwar, S.G., Patil, V.S., Singh, S.R., Maji, A.K., 
2010. A GIS Based Land Use Suitability Assessment in Seoni District, Madhya Pradesh, India. Tropical Ecology 51(1), 41-54.

Cohen, M.M., 2014. Tulsi-Ocimum sanctum: A herb for all reasons. Journal of Ayurveda and Integrative Medicine 5(4), 251-259. http://doi.org/10.4103/09759476.146554

Dharumrajan, S., Naidu, L.G.K., Lalitha, M., Vasundhara, R., Anilkumar, K.S., Hrdge, R., Singh, S.K., 2016. Assessment of suitability of fallow lands for major medicinal plants in Tamil Nadu. International Journal of Bio-resource and Stress Management 7(4), 877-884

Dumanski, J., Bindraban, P.S., Pettapiece, W.W., Bullock, P., Jones, R.J.A., Thomasson, A., 2002. Land classification, sustainable land management, and ecosystem health. In Encyclopaedia of Life Support Systems. Oxford, UK, II: EOLSS Publishers.

FAO, 1976. A framework for land evaluation. food and agriculture organization of the United Nations, FAO Soils Bulletin 32, Rome, 72p.

Keshavarzi, A., Sarmadian, F., Ahmadi, A., 2011. Spatiallybased model of land suitability analysis using Block Kriging. Australian Journal of Crop Science 5, 1533-1541.

Klingebiel, A.A., Montgomery, P.H., 1961. Land capability classification, AgricultureHandbook 210, Soil Conservation Service, USDA. Washington, D. C., 105-108.

Mohana, P., Mariappan, N.V.E., Manoharan, N., 2009. Land suitability analysis for the part of ParambikulamAliyar command area, Udumalpet Taluk using remote sensing and GIS Techniques. International Journal on Design and Manufacturing T Echnologies, 3(2), 98-102. doi:10.18000/ijodam.70069

Naidu, L.G.K., Ramamurthy, V., Challa, O., Hegde, R., Krishnan, P., 2006. Manual soil-site suitability criteria for major crops" NBSS Pub!. No. 129, NBSS\&LUP, Nagpur 118 pp. Natarajan, A., Janakiraman, M., Manoharan, S., Anil Kumar, K.S., Vadivelu, S., Sarkar, D., 2010. Assessment of land degradation and its impacts on land resources of Sivagangai block, Tamil Nadu, India. In: Zdruli, P., Pagliai, M., Kapur, S., Cano, A.F. (Eds.), Land degradation and desertification: Assessment, Mitigation and remediation DOI. 10.1007/978-90-481-8657-0_18. Springer, Netherlands, 235-252.

Rajendran, K., Balaji, P., JothiBasu, M., 2008. Medicinal plants and their utilization by villagers in southern districts of Tamil Nadu. Indian Journal of Traditional Knowledge 7(3), 417-420.

Ramamurthy, V., Singh, S.K., 2015. Land use Planning for important medicinal and aromatic plants in Karnataka. NBSS\&LUP publication 1081, Nagpur 22.

Requier, J., Bramao, D.L., Cornet, J.P., 1970. A new system of soil appraisal in terms of actual potential productivity. AGL. TESR/70/6, FAO, Rome, 38.

Sharma, M.L., Pandey, M.B., Khanna, B.K., Kappor, L.D., 1972. Essential oils from plant raised on alkaline soils. Indian perf., 16(1), 27-30.

Soil Survey Division Staff, 2003. Keys to soil taxonomy, $9^{\text {th }}$ Edition, USDA, NRCS: Washington, D.C. 